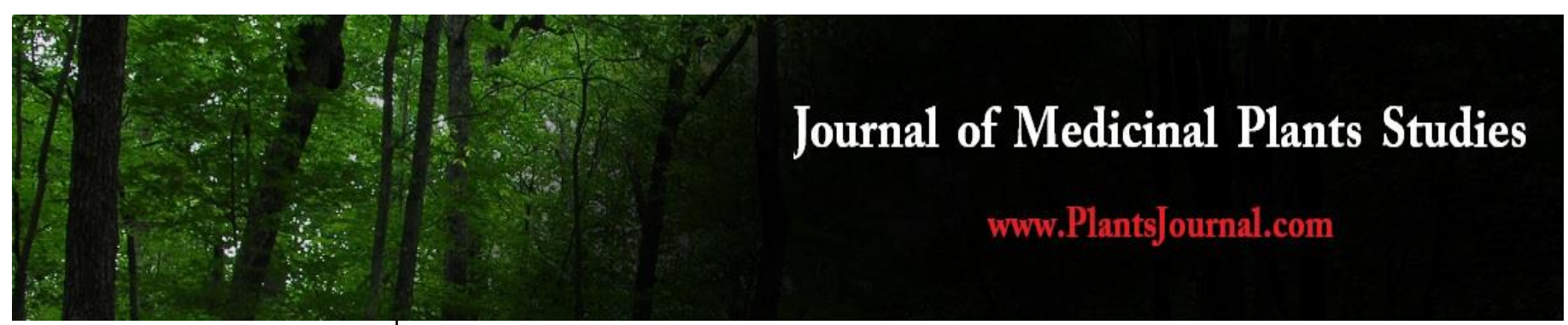

ISSN (E): 2320-3862

ISSN (P): 2394-0530

NAAS Rating: 3.53

www.plantsjournal.com

JMPS 2020; 8(3): 10-13

(C) 2020 JMPS

Received: 08-03-2020

Accepted: 10-04-2020

Kalyani Saikia

Department of Pharmacy

Regional Institute of

Paramedical and Nursing

Sciences, Zemabawk, Aizawl,

Mizoram, India

Department of Pharmacognosy

Rahman Institute of

Pharmaceutical Sciences and

Research, Tepesia, Kamarkuchi,

Kamrup (M), Assam, India

\section{R Lalawmpuii}

Department of Pharmacy

Regional Institute of

Paramedical and Nursing

Sciences, Zemabawk, Aizawl,

Mizoram, India

\section{Pratap Kalita}

Department of Pharmacy

Regional Institute of

Paramedical and Nursing

Sciences, Zemabawk, Aizawl,

Mizoram, India
Corresponding Author:

Kalyani Saikia

Department of Pharmacy

Regional Institute of

Paramedical and Nursing

Sciences, Zemabawk, Aizawl,

Mizoram, India

Department of Pharmacognosy

Rahman Institute of

Pharmaceutical Sciences and

Research, Tepesia, Kamarkuchi,

Kamrup (M), Assam, India

\section{Evaluation of in-vitro antioxidant and cytotoxic activity of methanolic leaf extract of Blumea lanceolaria ROXB}

\author{
Kalyani Saikia, R Lalawmpuii and Pratap Kalita
}

\section{Abstract}

The present study describes antioxidant activities and cytotoxic activity of methanolic leaf extract of Blumea lanceolaria (Astereceae). The antioxidant activities were determined by in-vitro screening models; DPPH radical scavenging activity, Nitric oxide scavenging activity along with the estimation of total phenolic and flavfonoid content. From the result of DPPH radical scavenging activity and Nitric oxide scavenging activity the extract shows antioxidant activity with the $\mathrm{IC}_{50}$ values $55.56 \mu \mathrm{g} / \mathrm{ml}$ and $70.60 \mu \mathrm{g} / \mathrm{ml}$ respectively. The total phenolic and flavonoid content were found to be 60.20 gallic acid equivalent /gm of dried extract and 60 quercetin equivalent/gm of dried extract. The cytotoxic activity was investigated by MTT assay on HeLa (Human cervical cancer) cell line. The MTT assay suggest that the leaf extract of Blumea lanceolaria exhibited moderate cytotoxicity $(20<\mathrm{IC} 50>100)$ against HeLa cell lines with $\mathrm{IC}_{50} 95.63 \mu \mathrm{g} / \mathrm{ml}$.

Keywords: Blumea lanceolaria, antioxidant activity, total phenolics and flavonoid, MTT assay

\section{Introduction}

Natural products are important source of new drugs, new drug leads and new chemical entities and are being used for the treatment of several ailments in North-East India. The main characteristic of an antioxidant is its ability to trap free radicals. Antioxidants act by interfering with the oxidation process by reacting with free redicals. Plant molecules, their semi-synthetic and synthetic derivatives are important sources of antitumor drugs. Herbal antioxidants have been successfully employed as rejuvenators, for several centuries in the Indian systems of alternative medicine ${ }^{[1]}$. Flavonoids and phenolic acids are particularly effective as they are known to exhibit anticarcinogenic, antiviral, antiinflamatory and antiallergic properties. Blumea lanceolaria (Roxb.) Druce belonging to the family Asteraceae commonly has known as Baurze, Terapaibi, Ghanashyam haak is a perennial herb available in different states of India. Blumea lanceolaria is a unique traditional medicine used in Mizoram and Africa as well. A decoction of the leaves is taken orally to treat stomach ulcers, dysentery and wounds [2]. The Chakma peoples traditionally used the paste of leaves for the treatment of fever by applying on head and forehead. In addition the leaves are edible and also used as flavouring agent. In Assam people use the juice of the leaves of Blumea lanceolaria in the treatment of cough.

\section{Materials and methods}

The leaves of Blumea lanceolaria were collected from Thenzawl area, Aizawl, Mizoram during October 2016. The plant is identified by Botanical Survey of India, Eastern Regional Centre, Shillong-793003; the voucher specimen is (BSI/ERC/2010) RP/080.

Preparation of extract: The collected fresh leaves of the plant were cleaned, washed and dried under shade for three weeks. The air dried leaves were crushed and the powdered leaves $(400 \mathrm{gm})$ were extracted at room temperature successively by Soxhlet apparatus using petroleum ether followed by chloroform and methanol as solvent respectively for 50 hours. The solvents were recovered by distillation under reduced pressure using rotary vacuum evaporator to obtain crude petroleum ether extract $(15 \mathrm{gm})$, chloroform extract $(13 \mathrm{gm})$ and methanol extract $(12 \mathrm{gm})$. The extracts were kept in air tight container and the methanol extract was used for evaluation of different biological activities. 
Antioxidant activity: In this study the in-vitro antioxidant activity of methanolic leaf extract of Blumea lanceolaria was evaluated by DPPH radical scavenging method and nitric oxide scavenging method and was compared with standard.

DPPH radical scavenging activity: DPPH radical scavenging activity was evaluated according to the method described by Blois (1958) with minor changes [3]. Butylated hydoxy anisole (BHA) was used as reference standard. $0.5 \mathrm{ml}$ of DPPH solution in methanol $(0.1 \mathrm{mM})$ was mixed with $3 \mathrm{ml}$ of the extract and $3 \mathrm{ml}$ of standard prepared in various concentrations $(10,20,40,60,80,100 \mu \mathrm{g} / \mathrm{ml})$, respectively. The extract and standards were incubated for 30 minutes at $37^{\circ} \mathrm{C}$. Absorbance was measured at $517 \mathrm{~nm}$ using ultravioletvisible (UV-Vis) spectrophotometer. Control reading was also taken and $\mathrm{IC}_{50}$ value was determined ${ }^{[4]}$. The scavenging effect of DPPH free radical was calculated using the following equation,

$$
\% \text { inhibition }=\frac{\text { absorbance of control }- \text { absorcanc of test }}{\text { absorbance of control }} \times 100
$$

Assay of nitric oxide scavenging activity: Nitric oxide scavenging activity can be estimated by the use of Griess III Osvoy reaction ${ }^{[5]}$. For the experiment, sodium nitroprusside $(10 \mathrm{mM})$ in phosphate buffered saline was mixed with different concentrations $(10,20,40,60,80,100 \mu \mathrm{g} / \mathrm{ml})$ of methanol extract were dissolved in methanol and incubated at $30^{\circ} \mathrm{C}$ for 2 hours. The same reaction mixture without the extract but the equivalent amount of methanol served as the control. After the incubation period, $0.5 \mathrm{ml}$ of Griess reagent (1\% sulfanilamide, $2 \% \quad \mathrm{H}_{3} \mathrm{PO}_{4}$ and $0.1 \% \quad \mathrm{~N}$-(1-naphthyl) ethylene diamine dihydrochloride) was added. The absorbance of the reaction mixture was immediately read at $550 \mathrm{~nm}$. Inhibition of nitrite formation by the plant extract and the standard antioxidant BHA were calculated relative to the control. Inhibition data (percentage inhibition) were linearized against the concentrations of extract and standard antioxidant. $\mathrm{IC}_{50}$ which is an inhibitory concentration of each extract required to reduce $50 \%$ of the nitric oxide formation was determined ${ }^{[6]}$. The scavenging effect of nitric oxide was calculated using the following equation,

$$
\% \text { inhibition }=\frac{\text { absorbance of control }- \text { absorcanc of test }}{\text { absorbance of control }} \times 100
$$

Determination of total phenolic content: The total phenolic content was determined using the method of Mc Donald et al. with modifications ${ }^{[8]}$. Calibration curve was prepared by mixing $1 \mathrm{ml}$ of methanolic solution of Gallic acid (10, 20, 40, 60,80 , and $100 \mu \mathrm{g} / \mathrm{ml}$ ) with $5 \mathrm{ml}$ Folin-Ciocalteu reagent (diluted tenfold). After 3 minutes, $4 \mathrm{ml}$ of sodium carbonate solution $(0.7 \mathrm{M})$ was added, and the mixture was allowed to stand for $1 \mathrm{hr}$ at room temperature. Absorbance was measured at $765 \mathrm{~nm}$ using UV-Vis spectrophotometer. $1 \mathrm{ml}$ extract $(50 \mu \mathrm{g} / \mathrm{ml})$ was also mixed with the above reagents and after 1 $\mathrm{hr}$ the absorbance was measured to determine total plant phenolic content. From the calibration curve, the amount of phenolic compounds was determined and expressed as milligrams of Gallic acid equivalent (GAE)/g of the extract ${ }^{[4]}$, table 2 .

Determination of total flavonoid content: The total flavonoid content was determined by the aluminium chloride method. $1 \mathrm{ml}$ of the extract $(50 \mu \mathrm{g} / \mathrm{ml})$ was mixed with $2 \mathrm{ml}$ of distilled water. After 5 minutes, $3 \mathrm{ml}$ of $5 \%$ sodium nitrite
$\left(\mathrm{NaNO}_{2}\right)$ and $0.3 \mathrm{ml}$ of $10 \%$ aluminium chloride $\left(\mathrm{AlCl}_{3}\right)$ were added. After 6 minutes, $2 \mathrm{ml}$ of $\mathrm{NaOH}(1 \mathrm{M})$ was added, and the volume was made up to $10 \mathrm{ml}$ with distilled water. After 1 $\mathrm{hr}$, absorbance reading was taken at $510 \mathrm{~nm}$. A standard curve was prepared with Quercetin at different concentrations (10, $20,40,60,80$, and $100 \mu \mathrm{g} / \mathrm{ml})$. From the calibration curve of the reference standard, the total flavonoid content was determined and expressed as milligrams of Quercetin equivalent $(\mathrm{QE} / \mathrm{g})$ of extract ${ }^{[4]}$, table 2 .

Evaluation of MTT assay (MTT Assay for anticancer activity): Cell lines and Culture medium: A HeLa (Human cervical cancer) cell line was procured from National Centre for Cell Sciences (NCCS), Pune, India. The stock cells were cultured in DMEM supplemented with $10 \%$ inactivated Fetal Bovine Serum (FBS), penicillin (100 IU/ml), streptomycin $(100 \mu \mathrm{g} / \mathrm{ml})$ and amphotericin B $(5 \mu \mathrm{g} / \mathrm{ml})$ in a humidified atmosphere of $5 \% \mathrm{CO}_{2}$ at $37^{\circ} \mathrm{C}$ until confluent. The cells were dissociated with trypsin solution $(0.2 \%$ trypsin, $0.02 \%$ ethylenediaminetetra acetic acid, $0.05 \%$ glucose in PBS). The stock cultures were grown in $25 \mathrm{~cm}^{2}$ culture flasks, and all experiments were carried out in 96 micro titre plates ${ }^{[9]}$.

Procedure: The cytotoxic activity of the methanol leaf extracts of Blumea lanceolaria was investigated using the MTT assay (Sigma, USA) on human cervical cancer cell line (HeLa). The cells were seeded in 96-well plates at a density of $1 \times 10^{4}$ cells per well. After incubation for $20-24 \mathrm{~h}$, the cells with 70-80\% confluency were treated with the extracts at different concentrations $(10,20,60,80,100 \mu \mathrm{g} / \mathrm{ml})$ and incubated for $72 \mathrm{~h}$. Then, $20 \mu \mathrm{L}$ of MTT $(5 \mathrm{mg} / \mathrm{ml})$ solution was added to cells per well, and the plate was moved to a cell incubator for another $4 \mathrm{~h}$. The medium was removed, and 150 $\mathrm{ml}$ of DMSO (dimethyl sufoxide) was added to the cells. The plate was gently shaken for $15 \mathrm{~min}$ to dissolve the formazan crystals generated by proliferating cells, and the measurement was performed using a Spectramax M2 Microplate Reader (Molecular Diagnostic, Inc.) at a wavelength of $550 \mathrm{~nm}$. Relative viability was calculated taking wells with non treated cells as $100 \%$ control. The results are expressed as mean values $( \pm \mathrm{SD})$ of six repeats. The $\mathrm{IC}_{50}$ values were obtained by nonlinear regression using the GRAPHPAD program [10]. In this screening program, we adopted the criteria of the American National Cancer Institute (NCI) to consider a crude extract promising for further purification based on the $\mathrm{IC}_{50}$ values as active, moderately active or inactive, when the $\mathrm{IC}_{50}$ values are lower than $20 \mu \mathrm{g} / \mathrm{ml}$, from 20 to $100 \mu \mathrm{g} / \mathrm{ml}$, or higher than $100 \mu \mathrm{g} / \mathrm{ml}$, respectively in order to discover and develop potential anticancer natural compounds ${ }^{[11]}$.

\section{Results and discussion}

Determination of DPPH radical scavenging activity: In the DPPH assay, the DPPH radical is scavenged by antioxidants through the donation of electrons forming the reduced DPPH. The colour changes from purple to yellow after reduction, and the accompanying decrease in absorbance can be quantified at wavelength $517 \mathrm{~nm}$. Inhibition concentration $\left(\mathrm{IC}_{50}\right)$ parameter was used for the interpretation of the results from DPPH method. The discoloration of the sample was plotted against the sample concentration in order to calculate the $\mathrm{IC}_{50}$ value [4]. The percent inhibition of extract and BHA are shown in table 1. Antioxidant activity in the form of $\mathrm{IC}_{50}$ values of the extract was calculated as $55.56 \mu \mathrm{g} / \mathrm{ml}$ compared to standard BHA, which exhibited $12.76 \mu \mathrm{g} / \mathrm{ml}$. 
Assay of nitric oxide scavenging activity: Nitric oxide (NO) is an important chemical mediator generated by endothelial cells, macrophages, neurons, etc. and is involved in the regulation of various physiological processes. Excess concentration of NO is associated with several diseases. NO scavenging capacity is determined by the decrease in the absorbance at $550 \mathrm{~nm}$, induced by antioxidants ${ }^{[6]}$. The results of NO scavenging activity of the extracts and BHA are shown as percent of $\mathrm{NO}$ scavenging in table 1 . The $\mathrm{IC}_{50}$ values were found to be $70.60 \mu \mathrm{g} / \mathrm{ml}$ and $26.58 \mu \mathrm{g} / \mathrm{ml}$ respectively.

Determination of total phenolic content: Phenolics and flavonoids have been reported to be the main phytochemical responsible for antioxidant capacity of fruits and vegetables. Plant-derived polyphenols display characteristics inhibitory pattern towards oxidative reaction in vitro and in vivo. In this study, a total phenolics concentration equivalent of Gallic acid was estimated according to Folin- Ciocalteu method. ${ }^{[4]}$. The total phenolic content of the extract was expressed as Gallic acid equivalent/gm and was found to be $67.20 \mathrm{mg}$ $\mathrm{GAE} / \mathrm{g}$.

Determination of total flavonoids content: Flavonoids are a group of polyphenolic compounds, which exhibit several biological effects such as anti-inflammatory, anti-hepatotoxic, anti-ulcer, anti-allergic, anti-viral and anti-cancer activities ${ }^{[13]}$. They are capable of effectively scavenging the reactive $\mathrm{O}_{2}$ species because of their phenolic hydroxyl groups and so they are potent antioxidants also. The total flavonoid content of methanol leaf extracts of Blumea Lanceolaria was found to be $60 \mathrm{mg} / \mathrm{gm}$ of extract in terms of Quercetin equivalent.

Evaluation of MTT assay: In order to assess the cytotoxic effect of Blumea lanceolaria methanol extract on HeLa (Human cervical cancer) cell lines, MTT assay was performed. In the present study, cytotoxicity of plants extract showed increase in cell death with the increase in concentration of plant extracts on HeLa cell lines. The cytotoxicity of plants extract showed increase in cell death with the increase in concentration of plant extracts. As a positive control Doxorubicin was used which showed active cytotoxic activity against HeLa cell lines. The \% cell viability of the extract was reduced as the concentration is increased and $\mathrm{IC}_{50}$ value was found to be 95.63 . Thus, according to NCI [11], from the result in MTT assay suggest that the leaf extract of Blumea lanceolaria exhibited moderate cytotoxicity $\left(20<\mathrm{IC}_{50}>100\right)$ against HeLa cell lines.

Table 1: $\mathrm{IC}_{50}$ values of methanolic leaf extract of Blumea lanceolaria

\begin{tabular}{|c|c|c|c|}
\hline \multicolumn{4}{|c|}{ IC $_{\mathbf{5 0}}$ value $(\boldsymbol{\mu} \mathbf{g} / \mathbf{m l})$} \\
\hline Test/standard & DPPH radical scavenging activity & NO radical scavenging activity & MTT assay \\
\hline MeOH leaf extract & 55.56 & 70.60 & 95.63 \\
Standard & 12.76 & 26.58 & 5.95 \\
\hline
\end{tabular}

Table 2: Total phenolic and flavanoid content of methanolic leaf extract of Blumea lanceolaria

\begin{tabular}{|c|c|c|}
\hline Extract & $\begin{array}{c}\text { Total phenolic content } \\
\text { Gallic acid equivalent /gm of dried extract }\end{array}$ & $\begin{array}{c}\text { Total flavanoid content } \\
\text { Quercetin equivalent/gm of dried extract }\end{array}$ \\
\hline $\mathrm{MeOH}$ leaf extract & 67.20 & 60 \\
\hline
\end{tabular}

\section{Conclusion}

Searching plant sources may bring new natural products into pharmaceutical, cosmetic and food production. On the basis of the results obtained in the present study, the methanol leaf extract of Blumea lanceolaria possess significant antioxidant and cytotoxic activity. Presence of phenol and flavonoid compounds may account for this fact. So it can be concluded that the leaves of Blumea lanceolaria is a good natural medicine.

\section{Acknowledgement}

The authors are thankful to Director of Regional Institute of Paramedical and Nursing Sciences for financial assistance. The authors also thank Department of Biotechnology, Mizoram University for their help.

\section{References}

1. Patel Chirag J, Tyagi Satyanand, Halligudi Nirmala, Yadav Jaya, Pathak Sachchidanand, Shankar Pratap, Antioxidant activity of herbal plants: a recent review. Journal of Drug Discovery and Therapeutics. 2013; 1:1-8.

2. Mishra VK, Kumar Passari Ajit, Vanlalhmangaihi K, Senthil Kumar Nachimuthu, Singh Bhim Pratap. Antimicrobial and antioxidant activity of Blumea lanceolaria (Roxb.). Journal of Medicinal Plants Research. 2015; 9:84-90.

3. Blois MS. Antioxidant determinations by the use of a stable free redical. Nature: determination of antioxidant andantimicrobial activities of medically important mushrooms using different solvents and chemical composition via GC/MS analyses, edited by Avci E, Avci AG, Kose AD, 429-434, Corum, Turkey, 1958.

4. Lalawmpuii R, Lalhriatpuii TC, Lalzikpuii, Lalengliani K, Ghosh SK. Qualitative phytochemical screening and evaluation of in-vitro antioxidant activity of Callicarpa arborea Roxb, an ethno medicinal plant of Mizoram, North East India. Asian Journal of Pharmaceutical and Clinical Research. 2015; 8:202-205.

5. Garrat DC. The Quantitative analysis of Drugs, Chapman and Hall Ltd, Japan, 1964, 456-458.

6. Parul Rozina, Kundu SK, Saha Pijush, In vitro nitric oxide scavenging activity of methanol extracts of three Bangladeshi medicinal plants. The Pharma Innovation. 2013, 12:83-88.

7. Oyaizu M. Studies on products of browning reaction: Antioxidative activity of products of browning reaction. Jpn J Nutr. 1986; 40:307-315.

8. Mc Donald S, Prenzler PD, Autolovich M, Robards K. Phenolic content and antioxidant activity of olive oil extracts. Food Chem. 2001; 73:73-84.

9. Mosmann T. Rapid colorimetric assay for cellular growth and survival: application to proliferation and cytotoxicity assays. J Immunol Methods. 1983; 65:55-63.

10. Mariana Laundry de Mesquita, Jose Elias de Paulab, Claudia Pessoa, Manoel Odorico de Moraes, Leticia Veras Costa-Lotufo, Raphael Grougnet, Sylvie Michel, Laila Salmen Espindola, Cytotoxic activity of Brazilian Cerrado plants used in traditional medicine against cancer 
cell lines. Journal of Ethno pharmacology.2009; 123:439445.

11. Silva Alberto Ramos, Carreon FT, Figueroa Mario, Arellanez AG, Garcia Aida Rodriguez, Luis J, Arnaut Hamlet Aviles, Anticancer potential of Thevetia peruviana fruit methanolic extract. BMC Complementary and Alternative Medicine. 2017; 17:241.

12. Jamuna $\mathrm{S}$, Paulsamy $\mathrm{S}$, Karthika K. Screening of in vitro antioxidant activity of methanolic leaf and root extracts of Hypochaeris radicata L. (Asteraceae). Journal of Applied Pharmaceutical Science. 2012; 2:149-154.

13. Subhadra Devi V, Kumar Asok K, Umamaheswari M, Sivashanmgam AT. In-vitro antioxidant activity of Vetiveria zizanioides root extract. Tanzania Journal of Health Research. 2010; 12:1-8t. 